\section{REDES SOCIAIS: UMA NOVA PERSPECTIVA DO ESPAÇO}

As redes sociais trouxeram uma nova perspectiva para compreender o espaço. Não o espaço natural ou físico, mas o espaço entendido como lócus de comunicação, interação e negócios. Por meio das redes, os indivíduos se organizam em nichos virtuais e interagem com outros com quem compartilham assuntos de interesse, não importando mais se, no plano físico, essa interação se dá no nível local ou global. Essa noção ampliada do espaço acarreta grandes consequências para a vida das pessoas e organizações, embora tanto umas como as outras ainda estejam apenas começando a descobri-las.

Falemos primeiro das pessoas. Elas precisam aprender a apresentar a sua identidade virtual, desenvolvendo uma estratégia coerente com seus objetivos - sejam eles pessoais, profissionais, políticos etc. Nossa identidade virtual é uma importante forma de criar e reforçar afinidades, e de sermos reconhecidos no novo espaço de interação. Para administrá-la, é necessário ter uma estratégia de persona virtual, tendo em conta que nossa identidade será formada pelo conjunto de impressões deixadas no espaço virtual de interação.

E essa nova forma de interação das pessoas não afeta só a elas, mas também às organizações, sejam empresas ou governos. Em primeiro lugar, porque as obriga a serem mais flexíveis com seus empregados. Profissionais que trabalham intensamente com informação e conhecimento passam a demandar de seus empregadores maior flexibilidade para interagir nas redes sociais. Novamente é de espaço que estamos falando: o trabalho deixa de ser confinado ao espaço físico controlado pela empresa, e se expande para o novo espaço - maior, virtual - de interação. De um lado, essa situação pode gerar conflito de interesses: os melhores profissionais podem se tornar visíveis a outras companhias, empregados podem acabar expondo informações sensíveis sobre as organizações, e assim por diante.
De outro, hoje em dia as organizações não têm mais como negar que seus profissionais, de uma forma ou de outra, usem a interação virtual. Sendo assim, o melhor é preparar uma estratégia institucional adequada e treinar os profissionais, em vez de tentar adiar ou impedir a mudança.

Além disso, as redes sociais afetam a estrutura de comunicação das organizações. Antes das redes sociais, estas tinham mais controle sobre seus canais de comunicação. Agora, elas precisam interagir em espaços não mais sob seu controle. A interação com funcionários, em redes sociais fechadas, pode até ser tranquila uma vez que fique claro que o espaço é institucional. No entanto, consumidores e grupos da sociedade civil podem se organizar como quiserem pelas redes sociais, forçando as organizações a entrarem em uma interação que não é mais, nem de longe, controlado por elas.

A primeira reação de empresas e governos pode ser defensiva. No entanto, também é possivel pensar o espaço virtual de forma positiva. A interação permite, por exemplo, respostas rápidas em situações de conflito. Permite também melhorar o diálogo com consumidores e cidadãos, antecipando demandas e recolhendo sugestões para a melhora de produtos ou serviços. Em suma, ao mesmo tempo que as redes sociais desafiam estruturas de comunicação institucionalizadas, também oferecem oportunidades de inovação. Adaptar-se exige uma quebra de paradigma e causa resistências, mas as organizações que se adaptarem mais rapidamente haverão de colher melhores resultados do que aquelas que evitarem ocupar os novos espaços.

A expansão das redes sociais está apenas começando. Indivíduos, empresas e governos precisam, portanto, manter uma atitude de aprendizado diante desse fenômeno que emerge de ações descentralizadas. Os riscos são inevitáveis, mas o espaço novo está aí para ser experimentado e conquistado.

\section{"As redes sociais desafiam as estruturas de comunicação tradicionais e a própria noção de espaço"}

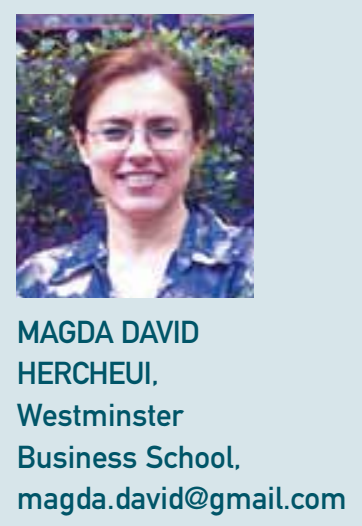

